\title{
Research on Interaction between Party Construction Work and Ideological and Political Education for University Students based on Synergy Theory Qing Wu, Hongjuan Ding
}

\author{
Shanghai University of Engineering Science, Shanghai, 201620, China
}

Keywords: synergy theory;, party construction for university students; ideological and political education

\begin{abstract}
Both the party construction work and ideological and political education work for university students are important in universities, the two are both different and link with and promote each other. In this paper, the synergy theory is used to discuss the difference and consistency between the party construction work and ideological and political education work for university students, it is thought that a synergy effect can be generated from the aspects of objective synergy, faculty synergy and resource synergy to improve the overall efficiency and achieve the benign interaction and supplementation of advantages between the university party construction and ideological and political education for university students by playing the functions of various system elements.

University students are the future of our country, the backbone of construction cause of socialism with Chinese characteristics and an important group in the successor of the CPC, so we should continuously guide the university students to pursue a higher objective unremittingly, strengthen the belief of Marxism and build a lofty ideal. However, the party construction work and ideological and political education work for university students are both different and link with and promote each other. Based on the synergy theory, this paper is to discuss the organic combination between the party construction work and ideological and political education work for university students and generate a correlation effect, form an integral force and generate synergy effect, so as to improve the overall function of the two.
\end{abstract}

\section{Connotation of synergy theory}

In the beginning of the 1970s, German physicist Herman Haken who made outstanding contribution in the field of quantum optics proposed the basic concept of "synergetics" from ordered to disordered transformation, mainly including synergy effect, servo principle and self-organization principle, in which "synergy effect" means the result generated by the synergy action, and it is the integrated effect or collective effect generated by the interaction of a lot of subsystems in a complicated and open system.

Synergy theory means to apply the principle of synergetics based on the structural function characteristics of the composite system faced and achieve effective management to the system according to the expected objective of sustainable development, so as to achieve system coordination and generate a synergy effect. This theory indicates that there exists a role of cooperation, synchronization, coordination and mutual supplementation between elements consisting the system, between element and system, system and system, and system and environment, and this action will make the system form an overall force of $1+1>2$, so as to achieve the supplementation of advantages. Synergy effect means that in order to achieve the overall evolution objective of the system, the subsystems or departments cooperate, coordinate with and support each other to form a benign cycle.

\section{Research on relation between party construction and ideological and political education for university students}

The university party construction work and ideological and political education work for 
university students are two independent systems, which have formed respective characteristics and similarity in their development, but all of them contain the system of interaction among society, school, teacher and students, with a mutual connection. Researching and mastering the relation between the two can further generate a synergy effect, so as to improve the overall efficiency.

(II) Differences between the two

First, they have different concepts. The party construction work is an important part of base-level party construction work of universities, the party construction for university students is mainly targeted at the university students, being a main content to strengthen and improve the ideological and political work for university students. Ideological and political education means a social practice activity that a certain class, political party and social group use certain ideological concepts, political viewpoints and moral regulations to exercise purposeful, planned and organized influence on their members, so that they form the ideology and morality conforming to the demand of certain society and class.

Second, they have different subjects. The base-level party construction work for the university students is mainly involved in the development, cultivation, education of student party members and the construction of student party organization, and its subject are the student party joining activists, student party members and student party organization, while the subject of ideological and political education for university students is all university students.

Third, they have different work contents: the party construction for university students is to exercise influence on the party members and party organization through purposeful, planned and organized education and management, the work objective is to maintain the advancement of party members and party organization, lead and promote the better and rapider development of various causes in universities. The ideological and political education for university students is aimed to shape the perfect ideological and moral quality and personality of university students.

(II) Connection between the two

1. The party construction for students is an important premise to ensure the quality of ideological and political education. At present, the reform of higher education management reform and diversification of information shock the university students' growth environment, political belief, ideal faith and value orientation etc. in a certain extent, and bring challenge to the ideological and political education for the university students. In this situation, strengthening the party construction for university students cannot only ensure the stable political leading position of CPC in universities, and ensure the publicity of theory and proposition of the CPC among young students, but can also arm the students' brain with the theoretical system of socialism with Chinese characteristics and guide them to grow healthily. Therefore, the party construction for students in universities is an important premise to ensure the quality of ideological and political education for university students.

2. Party construction for university students is the organization guarantee to carry out ideological and political education. The party construction for university students is an important part of party construction in universities, which means the practical activity of cultivating, educating and managing the party joining activists and student party members among the university students in a purposeful, planned and organized manner. The university students are in an important period of forming the world concept, life concept and value concept. With more and more students joining in the party member team, the basic-level party organization has become a platform of learning and communication with them. The basic-level organization of universities is the base for all work and fighting strength of party construction in universities ad the promoter, organizer and practitioner to publicize and carry out the theoretical system of socialism with Chinese characteristics and the line, guideline and policy of the CPC, playing the role of battle fortress. The excellent student party members and party organizations play the role of pioneer model in the building of excellent learning style to drive more students to reconstruct world concept and value concept, so as to comprehensively improve their quality.

3. Ideological and political education is an effective approach to promote the party construction for university students. The correct ideological and political education will be beneficial to improve 
the ideological and political quality of all students, guide the excellent students to understand the nature and purpose of the CPC more deeply, understand and identify the basic theory, line, outline and policy in various periods of the CPC, make the party joining activist further correct their motivation of party joining, further enhance the sense of responsibility and mission of the student party members and further firm the belief of communism. Therefore, ideological and political education has a promotion role to the party construction work in universities.

As stated above, there exists a relation of coordination, synchronization and cooperation between the party construction and ideological and political education for university students, and the sameness of structural elements of the two provides a powerful basis for the application of synergy theory.

\section{Research on party construction and ideological and political education for university students based on synergy theory}

Using the synergy theory to promote the benign interaction between party construction and ideological and political education for university students, form an overall force of $1+1>2$ and achieve the mutual supplementation of advantages is significant to promote the transformation of party construction for university students from experience to science and improve the ideological and political education work and the party construction work for university students. In this paper, the author thinks that the party construction and ideological and political education for university students can be started from the following

(I) Objective synergy, construct synergy mechanism between party construction work and ideological and political education for university students

Although there is difference between the party construction in university and party construction for students in work contents and objective, the two have similarities in guiding ideology and objective task. The guiding thoughts of both are Marxism-Leninism, Mao Zedong Thought, Deng Xiaoping Theory, the Important Thought of “Three Represents" and the Scientific Outlook on Development; in education contents, both take ideological and faith education and patriotism education as the main contents; the objective of both ideological and political education for university students and student party construction is to promote the comprehensive development of people. Therefore, the university student party construction and ideological and political education for university students should be developed in a synergic manner with the Scientific Outlook on Development as the guidance, comply with the work concept of people first and reform and innovation, and it is required to continuously innovate the method and approach for the student party construction and ideological and political education and construct the education model of "great ideology and politics" combining party construction and ideological and political education.

The ideological and political workers in universities should fully realize the important role of student party construction, and take it as a content of ideological and political education, and the ideological and political educators in universities should blend the method for party construction work in ideological and political education. Meanwhile, it is also required to fully realize the active role of student party construction work to the ideological and political education.

The student party members are the excellent groups among the students, who are the most effective force to directly contract and guide students, it is required to set up in the most active organizations like living campus, classrooms, associations and students' union, educate and manage the student party members, strengthen the construction in ideology, learning style, overall awareness and behavior regulations etc. and continuously enhance the absorption, influence, emotional appeal, cohesive force and fighting power, so as to play a good leading role for other university students in ideology, learning, work and life and improve the students' overall quality and the quality of higher education.

(II) Faulty synergy, realize the diversified combination of student party construction and ideological and political education team

Generally, the student party construction work team consists of the party affairs workers and tutors of party organization in each level, the ideological and political education team mainly 
consists of the political work cadres and ideological and political theory course teachers in universities. In the team construction, it is required to explore the mutual blending mode of party construction work team, student work team and ideological and political theory teachers. For example, in our university, the university leaders give ideological and political theory courses for the students by relying on "great class of knowing and doing", all faculty and staff participate, and the course covers the operation system and mechanism of "great moral education" of all students; and in the party school of students, ideological and political teachers are employed to give the class on the history of CPC.

In the team construction, it is also required to the "advantages of age, experience, prestige and feeling" of the old comrades and fully play the role of old cadres, old soldiers, old experts, old teachers and old models. In addition, it is also possible to fully use the social resources, appoint the excellent figures in schoolfellows and participate in the student party construction and ideological and political education work for students. For example, our school establishes a schoolfellow and tutor groups, who jointly act as the university career planning tutors, carry out the sailing, sail protection and voyage education, establish a complete set of topic system surrounding "university history education, passion and dream of university students, responsibilities and obligations of university students, deed of excellent CPC members, social responsibility of university students and ideal faith of party members" and carry out special lecture and forum every year and jointly participate in the student party member education and ideological and political education for university students.

(III) Resource synergy, set up a public platform for student party construction and ideological and political education

At present, the website of ideological and political education for work, QQ group and other network resources are playing a beneficial and active role. The establishment of special module for student party construction in the campus network can extend the student party construction work, further expand the space in which the two play role, break through the limitation of fixed time, meet the students' demand maximally and also expand the cannel of ideological and political channel and enhance the infection of ideological and political education. For example, it is possible to use the E-class website commonly used in universities in Shanghai to increase the party construction module, integrate theoretical learning, party affairs management, ideological education, learning communication and daily service, make use of the positive energy of the student party members, so as to drive more university students to approach to the party organization and achieve the ideological and political education to the students.

(IV) Effect reference, optimize the student party construction work and ideological and political education work

For example, the reference to the grading education method in ideological and political education work can more accurately understand and master the students' ideological trend, so that the political work can be guided by class and targeted; the party construction work and student party member education can also refer to the ideological and political education work, take the forms of class education and social practice, the perceptual practice can enhance the objective realization of university students to the basic knowledge of party, deepen the understanding to the policy of CPC, and rational knowledge can enhance the university students' identity to the basic guideline of the CPC and promote the sound development of their ideological quality.

In this paper, synergy theory is applied, it is thought that it can achieve the synergic development between university student party construction and ideological and political education from the aspects of objective synergy, faculty synergy and resource synergy, so as to improve the efficiency of university student party construction work and ideological and political education work and provide reference to play the student party members' role as pioneer role, the student party branch's role as fighting fortress and promote the comprehensive growth of university students. 


\section{Acknowledgments}

This paper is:

1. project of Chinese Association of Higher Education Student Work Research Branch (number: LX2014Y082)

2. ideological and political research project of Shanghai University of Engineering Sciences, Research on Interaction Mechanism between University Student Party Construction and Ideological and Political Education Based on Synergy Theory (number 2014GSZ05)

3. Party construction research project of Shanghai University of Engineering Sciences: Research on Model of Student Party Construction Work under the Background of Total Credit System

\section{References:}

[1] Liu Yu, On University Student Party Construction and Ideological and Political Education [J] Reform and Opening, 2011 (6)

[2] Li Zhao, On Role Playing Mechanism of Student Party Construction in Universities [J], China Electrical Power Education, 2010 (2)

[3] Wu Xiaoqing, Shen Dawei, Research on Construction of Synergy Mechanism of University Student Party Construction and Ideological and Political Education [J] Journal of Jiangsu Teachers University of Technology, 2012, 18(6)

[4] Qin Changhong, Research on Organic Blending of University Student Party Construction and University Student Ideological and Political Education [J], Journal of Ningxia Teachers University, 2010, 31(5)

[5] Li Xiang, Preliminary Discussion on University Student Party Construction and Ideological and Political Education [J], Journal of Nanchang Institute of Education, 2012 (12)

[6] Xu Zhongkui, Analysis and Innovation on Student Party Construction Work in Universities [J], Outside School Education of China (Theory), 2010 (10)

[7] Chen Meng, Yao Xiaoling, Analysis on Theory and Strategy for Synergy Combination of Student Party Construction and Ideological and Political Education in Universities [J], University Party Construction and Ideological and Political Education, 2013 (7)

[8] Zheng Guangxiang, Construction of Synergy Model of Ideological and Political Education in Universities [J], Journal of Harbin University, March 2014. 